\title{
ВИКОНАВСЬКА ІНТЕРПРЕТАЦІЯ ТА ІНТЕНЦІЯ ЯК ВИДИ ХУДОЖНЬОЇ ДІЯЛЬНОСТІ У ВОКАЛЬНОМУ МИСТЕЦТВІ
}

\author{
Наталія Могилевська \\ e-mail: mogylevska-nataliia@ukr.net; ORCID: 0000-0002-7102-2114 \\ Київський національний університет культури і мистецтв
}

\begin{abstract}
Анотація
Мета дослідження - обґрунтувати наявність і важливість виконавської інтерпретації та інтенції як основних видів художньої творчості у вокальному мистецтві. Методи дослідження. у процесі розв'язання завдань статті використано загальнонаукові, зокрема аналіз, синтез, інтерпретацію та узагальнення результатів, та спеціальні методи дослідження. Міждисциплінарне використання методологічного інструментарію мистецтвознавства, психолінгвістики, філософії мистецтва тощо дало змогу обґрунтувати наявність і значення виконавської інтерпретації та інтенції в мистецтві вокаліста. Зокрема, для концептуалізації уявлення про інтерпретацію та інтенції вокаліста застосовано психосемантичні методи, які досліджують свідомість, мотивацію, емоції особистості. Наукова новизна полягає в обґрунтуванні наявності та важливості виконавської інтерпретації та інтенції в мистецтві вокаліста. Висновки. Зазвичай музично-пісенний твір дає змогу виконавцю-вокалісту насамперед виразити власні погляди, переживання, відчуття, наміри і т. ін. Тому вираження свого внутрішнього світу, свого світовідчуття, утвердження свого «я» опосередковано (через інтерпретацію музичного твору) - чи не основне завдання, яке має розв'язати виконавець. Часто саме так музично-пісенний текст, який інтерпретує вокаліст, передусім стає засобом вираження його глибинних ментально-когнітивних намірів, тобто інтенцій. Тому в закладах підготовки майбутніх вокалістів повинні звертати увагу на забезпечення умов для ментальноціннісного розвитку студентів і формування у них відповідного духовного світогляду.
\end{abstract}

Ключові слова: інтерпретація; інтенція; виконавець; вокальне мистецтво; музично-пісенний текст; особистість

\section{Вступ}

Особливості виконавської інтерпретації та інтенції, зокрема у вокальному мистецтві, поряд з іншими індивідуальними складовими комплексу музичномовленнєвих ресурсів лежать в основі індивідуального виконавського стилю, який дає змогу увиразнити виконавця серед інших митців і сформувати уявлення про нього як неповторну творчу особистість, підґрунтям світогляду якої $€$ духовно-ціннісні диспозиції. Останні, власне, й визначають характер і спрямування виконавської інтерпретації та інтенції. 
Вісник Київського національного університету культури і мистецтв.

Серія: Сценічне мистецтво

Відтак аналіз і обґрунтування наявності й важливості виконавської інтерпретації та інтенції є актуальним напрямом мистецтвознавчих досліджень. Позаяк заклади підготовки майбутніх вокалістів насамперед орієнтуються не лише на формування в останніх професійного вміння інтерпретувати музично-пісенний твір, а й на забезпечення умов духовно-ціннісного розвитку студентів та формування у них відповідного світогляду.

\section{Аналіз останніх досліджень і публікацій}

Останнім часом з'являється дедалі більше праць, присвячених психологічним і семантичним аспектам виконавського мистецтва. До таких феноменів зараховуємо інтерпретацію та інтенцію.

Виконавська інтерпретація вже давно перебуває в колі наукового зацікавлення. Їй присвячено великий масив досліджень, зокрема у сфері музикології (О. Алексєєв (1964), В. Москаленко (2012)), музичної педагогіки (Г. Падалка (2008), О. Андрейко (2012)) та ін. Філософсько-методологічне підґрунтя концептуалізації поняття виконавської інтерпретації здебільшого визначене працями М. Бахтіна (2000, 1979).

До вивчення проблем «виконавської інтерпретації» зверталися як мистецтвознавці, так і педагоги-музиканти та психологи, розглядаючи цей феномен у різній площині:

- як художнє переосмислення та ретрансляцію авторського твору, у процесі чого відбувається діалектичне єднання об'єктивного - композиторського твору та суб'єктивного - особистісного переосмислення твору виконавцем (Бєлікова, 2011);

- як індивідуально-образне трактування виконавцем-музикантом авторського тексту, що зумовлюється ідеально-уявним розумінням твору (Саїк, 2000, с. 115-125);

- як сценічне трактування твору засобами виконавської майстерності: через темпоритм, динаміку, артикуляцію, фразування, акцентування тощо (Мальцев, 1991);

- як необхідну складову процесу сценічної творчості та провідну характеристику виконавського мистецтва, що своєю чергою обумовлює особливості музичної освіти (Рудницька, 1998);

- як динамічний творчий процес, в якому виконавець, зокрема піаніст, має донести до слухача смисл твору відповідно до композиторського задуму (Feinberg);

- «художньо-звукова реалізація музичного тексту в процесі виконання, яка залежить від задуму автора та його індивідуальних особливостей, принципів школи або напрямку, до яких належить виконавець» (Юцевич, 2003).

На жаль, дослідження виконавських інтенцій - не настільки популярний предмет наукових досліджень. Так, в Україні найбільш ґрунтовною працею у цьому напрямі, на нашу думку, є дисертація мистецтвознавця О. Фекете «Формування виконавської концепції музичного твору» (2009). У ній авторка досліджує виконавську концепцію як увиразнення інтенціональної діяльності свідомості музиканта-інтерпретатора, а також з метою формування художньої концепції розробляє поняттєвий апарат, який моделює інтенціональні механізми виконавської свідомості. 
Український учений І. Єргієв (2015) досліджує режисерські інтенції виконавської інтерпретації сучасної інструментальної музики.

Отже, можна стверджувати, що особливості вокальної інтерпретації та інтенції на сьогодні не отримали належного теоретичного осмислення у вітчизняній науці, що й зумовило актуальність цього дослідження.

Мета статті - обґрунтувати важливість і взаємозв'язок виконавської інтерпретації та інтенції як основних видів художньої творчості у вокальному мистецтві.

\section{Виклад основного матеріалу}

У сучасному музикознавстві простежуємо тенденцію щодо вивчення проблем виконавської інтерпретації, що зумовило появу поняття «інтерпретологія сфера музикознавства, що систематизує феномени виконавської діяльності музикантів у всьому розмаїтті їх прояву (теорія, історія, практика)» (Клюев, 2001, с.5) Художня інтерпретація (трактування) твору автора (письменника, композитора, постановника), яку втілює актор, танцівник, співак, музикант, диригент перед глядачами за допомогою виконавських засобів виразності, $є$ безумовною складовою виконавського мистецтва. Мистецьку виразну інтерпретацію простежуємо також і в музичному мистецтві, коли виконавець (співак, музикант, диригент) на основі творчого задуму композитора, не корегуючи партитури, утілює твір перед слухачами, застосовуючи свою техніку виконання та додаючи особисте емоційно-персоніфіковане прочитання тексту. У такий спосіб в інтерпретації поєднуються процес творення та відтворення. Співвідношення виконавського компонента й авторського може варіюватися як від окремої інтерпретації, так і від виконавського стилю та особистісних пріоритетів виконавця. Домінування інтерпретаційної виконавської складової під час виступу може перетворитися на імпровізацію, а в разі нестачі - на невиразне механічне відтворення нотного тексту. Адже композитор чи аранжувальник, утілюючи свій задум у текстовій формі, покладається на артиста, завдання якого спонукати слухача до відповідних емоцій та активного образотворення.

Українська дослідниця О. Андрейко (2012, с.4-7) розуміє індивідуальний стиль виконавця як особистісну категорію, де інтоноване виконання музичного твору $€$ відображенням персональної диспозиції, світогляду виконавця, що втілюється індивідуально-образними засобами технічної виразності. I хоча дослідження вченої, як і більшість інших, присвячені аналізу індивідуальності музикантів, основні їхні висновки проєктуються і у сферу вокально-пісенного мистецтва. Учена також підкреслює, що індивідуальний виконавський стиль - це не тільки сукупність індивідуальних особливостей виконавця, а й поєднання двох ментальних світів - автора твору та виконавця, що й визначає характер музично-виконавської інтерпретації, її духовно-ціннісну спрямованість (Андрейко, 2012, с.4-7).

Тому вже давно загальновідомим $€$ висновок, що виконання будь-якого музично-пісенного твору не можливе без інтерпретації з боку вокаліста його глибинного змісту й задуму. Основне завдання виконавця, як наголошує теоретик музикознавства О. Алексєєв (1964, с.7): «Органічно, переконливо відтворити процес становлення образної побудови твору». 
Вісник Київського національного університету культури і мистецтв. Серія: Сценічне мистецтво

І тут принагідно згадується відома позиція М. Бахтіна (1979, с.285), що будьякий істинно творчий текст завжди певною мірою є вільним і не передбачуваним емпіричною необхідністю одкровенням особистості, що втримує внутрішню необхідність, внутрішню логіку вільного ядра тексту. Філософ мистецтва наголошує: «Немає нічого абсолютно мертвого: у кожного смислу буде своє свято відродження» (Бахтин, 1979, с.373).

Різнобічно вивчаючи проблеми мовленнєвих жанрів, М. Бахтін звертається до питання впливу на індивідуума мовленнєвого оточення:

«[...] індивідуальний мовний досвід будь-якої людини формується та розвивається в безперервній і постійній взаємодії зі сторонніми індивідуальними висловлюваннями. Цей досвід певною мірою може бути охарактеризований як процес освоєння - більш-менш творчого - сторонніх слів (а не слів мови). Наша мова, тобто всі наші висловлювання [...], сповнена сторонніх слів, різного ступеня чужорідності чи різного ступеня засвоєння, різного ступеня усвідомленості та виокремлення». (Бахтин, 1986, с.460)

Суголосною $є$ думка літературознавця М. Гаспарова, що «всі мовні враження, що надходять ззовні, органічно вростають у мовний світ особистості» (Гаспаров, 1993, с.16).

У Музичній енциклопедії поняття «інтерпретація» (від лат. interpretatio роз'яснення, тлумачення) трактують як художнє тлумачення співаком, інструменталістом, диригентом, камерним ансамблем музичного твору в процесі його виконання, розкриття ідейно-образного змісту музики виразними і технічними засобами виконавського мистецтва (Ямпольский, 1974, с.550).

У Словнику іншомовних слів інтерпретація (з лат. роз'яснюю, перекладаю) це 1) роз'яснення, тлумачення, розкриття змісту чого-небудь; 2) творче виконання художнього твору, що ґрунтується на самостійному тлумаченні виконавця (мист.) (Словник іншомовних слів).

Тобто мистецьке тлумачення інтерпретації це фактично, як підкреслює В. Москаленко (2012), творче розкриття змісту художнього твору, що визначається ідейно-художнім задумом та індивідуальними особливостями артиста. Водночас, згідно з розумінням В. Москаленка (2012, с.15), виконавська інтерпретація «виражається в творчому прочитанні музичного твору та його озвучуванні без порушення внутрішньої структури і заміни задуманого композитором інструментарію».

Саме тому, напевно, українська дослідниця педагогіки мистецтва Г. Падалка має ґрунтовні підстави визначити виконавську інтерпретацію як основний вид художньої діяльності у виконавських мистецтвах. Зокрема, вона уточнює, що процес музичної інтерпретації містить не лише відтворювальні, репродуктивні аспекти, а й значний потенціал прояву з боку виконавця творчого ставлення до твору (Падалка, 2008). Виконавцю, як наголошує дослідниця, варто не тільки заглибитися в авторське відчуття образу та намагатися якомога повніше передати його у власному трактуванні, а й виявити власне розуміння тексту, виявити власні почуття, передати особливості власного сприйняття того, що створив автор твору (Падалка, 2008). 
У свою чергу М. Бахтін (2000, с.229-230) підкреслює діалогічність самого розуміння, яке він трактує як «бачення сенсу, але не феноменальне, а у вигляді живого смислу переживання і вираження, бачення внутрішньо осмисленого, так би мовити, самоосмисленого явища».

У виявленні глибинного смислу музично-пісенного тексту виконавської інтерпретації потрібно згадати й про інші психосемантичні особливості, позаяк ідеться про мовлення та характерні риси його спрямованості у комунікативній трансляції. Так, одним з важливих аспектів висловлювань, які водночас тісно пов'язані та фактично слідують з інтерпретації, є їхня інтенційна спрямованість.

У Великому тлумачному словнику сучасної української мови інтенцію (від лат. intentio - прагнення) описано як спрямування мислення людини на будь-який об'єкт, схильність свідомості до чого-небудь. Основою такої спрямованості або схильності є бажання, задуми, план дій, ціль. Найбільш наближеним за змістом до інтенції є поняття намір (Бусел ред., 2005).

І. Єргієв (2015) визначає інтенціональність як головне втілення основної ідеї-меседжу (надідеї), яку виконавець надсилає слухачеві/глядачу.

Загалом через виконання вокаліст реалізує завдання вираження інтенційного змісту музично-пісенного твору, відображеного в структурі авторського твору у вигляді текстових комунікативних тактик і стратегій. Так у виконаному вокалістом пісенно-звуковому тексті проявляються наміри (інтенції) поетапісенника, композитора та самого виконавця. Водночас, як підкреслює І. Єргієв (2015), інтенціональність, як фундаментальна властивість людської свідомості, часто демонструє збіг творчих позицій автора й виконавців.

Саме інтенції є чи не найважливішим психологічним складником діалогічної комунікації та дискурсу взагалі. М. Бахтін (1979, с.285) наголошує: «Подія життя тексту, тобто його справжня сутність, завжди розвивається на рубежі двох свідомостей, двох суб'єктів».

У разі виконавського мистецтва це можна зрозуміти як існування двох свідомостей - авторів музично-пісенного твору та виконавця-інтерпретатора. Це, перефразуючи висновки теоретиків інтент-аналізу, уможливлює об'єктивацію інтенційного простору мистецького дискурсу як сукупності інтенцій та інтелектуальних структур, які становлять психологічну основу цієї творчої сфери комунікації (Павлова и Гребенщикова, 2017, с.1).

Інтенції включені авторами в глибинний сенс змісту тексту музично-пісенного твору, який вокаліст ніби зчитує, сприймаючи крізь призму власної свідомості та досвіду. А далі виконавець виражає свої інтенції часто засобами вокальної експресії. Емоційна маркованість мовлення вокаліста-виконавця тісно пов'язана з психологічним змістом висловлювань і бажаннями, намірами, цілями співрозмовників. Крім того, саме емоційність багато в чому визначає «правильне» розуміння слухачами інтенційного сенсу виконуваного твору, що у свою чергу впливає на позитивні результати його сприйняття та більш-менш схожі загальні реакції глядацького залу.

Очевидно, що виконавець, відтворюючи звуковий текст твору, йде шляхом від глибинного виконавського задуму до способу його втілення через прийняті в соціумі мовні норми вираження смислів, пристосовуючи своє індивідуальне 
Вісник Київського національного університету культури і мистецтв.

Серія: Сценічне мистецтво

відчуття до універсальних людських відчуттів. Так він створює своєрідні власні поверхневі сенси.

О. Фекте взагалі розуміє виконавську діяльність як особливий рід музичного мислення, визначаючи саму концепцію музичного твору через явище інтенції. Концептуальну інтенцію вона розглядає з погляду відображення художнього світосприйняття особистості, домінантної форми виконавської активності та вектора комунікативної інтенції. Виконавська концепція визначає вектор смислоутворення, віддзеркалюючи масштаб особистості виконавця, та постає як категорія художньої свідомості (Фекте, 2009).

Водночас зрозуміло, що виконавські інтенції мають бути зрозумілі слухачеві/ глядачу. Тому принцип зрозумілості виконавських інтенцій, тобто критерій суб'єктивності їх розуміння має стати основним в їхньому вираженні через виконання музично-пісенного твору вокалістом.

Виявлення та/чи розуміння слухачем/глядачем інтенцій ґрунтується на суб'єктивному оцінюванні звукового тексту виконання, тобто насамперед на якісній характеристиці твору. Тому розуміння різними слухачами/глядачами інтенцій, які виражені в тексті, не може бути абсолютно тотожним. Відтак зрозуміло, що об'єктивація оцінки музично-пісенного тексту - це насамперед завдання професійних критиків, аналітиків чи теоретиків мистецтва, які можуть виокремити художні критерії аналізу, відповідно до яких можна говорити про експертне оцінювання виконання, у тому числі визначення інтенцій, виражених у пісенному мовленні вокаліста-виконавця.

I насамкінець варто наголосити, якщо у звичайній комунікації можливі безпосередні засоби та способи вираження інтенцій, то для вокального мовлення характерні тільки непрямі. Однак вони мають бути зрозумілими переважній більшості слухачів. Інакше виконавець-вокаліст зіштовхнеться з певними ускладненнями, які стосуватимуться як неможливості вираження власних намірів, основної ідеї музично-пісенного тексту, так і цілей усієї мистецької комунікації.

Наукова новизна. Отож можна простежити взаємовплив виконавської інтерпретації та інтенцій у мистецтві вокаліста. Безумовно аналіз й обґрунтування видів непрямих засобів і способів вираження інтенцій у вокальному виконавстві - перспективний напрям подальших досліджень.

\section{Висновки}

Отже, зазвичай музично-пісенний твір дає змогу виконавцю-вокалісту насамперед виразити власні погляди, переживання, відчуття, наміри і т. ін. Тому фактично вираження свого внутрішнього світу, свого світовідчуття, утвердження свого «я» опосередковано (через інтерпретацію музичного твору) - основне завдання, яке має розв'язати виконавець. Часто саме так музично-пісенний текст, який інтерпретує вокаліст, передусім стає засобом вираження його глибинних намірів, тобто інтенцій. Тому в закладах підготовки майбутніх вокалістів мають звертати увагу на забезпечення умов для ментально-ціннісного розвитку студентів і формування у них відповідного духовного світогляду. 


\section{СПИСОК ПОСИЛАНЬ}

Алексеев, А.Д., 1964. Интерпретация музыкальных произведений. На основе анализа искусства выдающихся пианистов XX века. Москва: Государственный музыкальнопедагогический институт им. Гнесиных.

Андрейко, О.І., 2012. Аксіологічний аспект формування індивідуального виконавського стилю музиканта. Науковий часопис НПу імені М. П. Драгоманова. Серія 16: Творча особистість учителя: проблеми теорії і практики, 17, с.4-7.

Бахтин, М.М., 1979. Эстетика словесного творчества. Москва: Искусство.

Бахтин, М.М., 1986. Проблема речевых жанров. В: Литературно-критические статьи.

Бахтин, М.М., 2000. Автор и герой: К философским основам гуманитарных наук. СанктПетербург: Азбука.

Бєлікова, В., 2011. Інтерпретація як специфічна основа музично-виконавської творчості. Актуальні питання мистецької педагогіки, [online] 1, с.135-138. Доступно: <http://apmp. kgpa.km.ua/Files/APMP01/34.pdf> [Дата звернення 12 серпня 2021].

Бусел, В.Т. ред., 2005. Великий тлумачний словник сучасної української мови. Київ: Перун. Єргієв, І., 2015. Режисерські інтенції виконавської інтерпретації сучасної інструментальної музики. Міжнародний вісник: культурологія, філологія, музикознавство, 2(5), с.145-150.

Інтерпретація. Словник іншомовних слів. [online] Доступно: <https://www.jnsm.com.ua/ cgi-bin/u/book/sis.pl?Qry=\%B2\%ED\%F2\%E5\%F0\%EF\%F0\%E5\%F2\%E0\%F6\%B3\%FF> [Дата звернення 12 серпня 2021].

Клюев, 0.,2001. Онтологиямузыки. Санкт-Петербург:Издательство Санкт-Петербургского государственного университета.

Мальцев, С., 1991. О психологии музыкальной импровизации. Москва: Музыка.

Москаленко, В.Г., 2012. Лекции по музыкальной интерпретации. Киев: Клякса.

Павлова, Н.Д. и Гребенщикова, Т.А., 2017. Интент-анализ постсобытийного дискурса в интернете. Психологические исследования, 10 (52), с.8.

Падалка, Г.М., 2008. Педагогіка мистецтва: (теорія і методика викладання мистецьких дисциплін). Київ: Освіта України.

Рудницька, О.П., 1998. Музика і культура особистості: проблеми сучасної педагогічної освіти. Київ: ІЗМН.

Саїк, Г.Ф., 2000. Емоційно-естетичні переживання музики через формування виконавської майстерності студентів. Наука і сучасність, 22 (2), с. 115-125.

Фекете, О.В., 2009. Формування виконавської концепції музичного твору. Автореферат дисертації кандидата мистецтвознавства. Харківський державний університет мистецтв імені І.П. Котляревського.

Юцевич, Ю., 2003. Музика: словник-довідник. Тернопіль: Навчальна книга-Богдан.

Ямпольский, И.М., 1974. Интерпретация. В: Келдыш, Ю.В. ред. Музыкальная энциклопедия. Москва: Советская энциклопедия. Т. 2.

Feinberg, S. The Composer and the Performer. [online] Available at: <http://math.stanford. edu/ ryzhik/Feinberg1.html> [Accessed 12 August 2021]. 


\section{REFERENCES}

Alekseev, A.D., 1964. Interpretatciia muzykalnykh proizvedenii. Na osnove analiza iskusstva vydaiushchikhsia pianistov XX veka [Interpretation of musical works. Based on an analysis of the art of outstanding pianists of the 20th century]. Moscow: Gnesin Russian Academy of Music. Andreiko, O.I., 2012. Aksiolohichnyi aspekt formuvannia indyvidualnoho vykonavskoho styliu muzykanta [Axiological aspect of the formation of individual performance style of the musician]. Naukovyi chasopys NPU imeni M. P. Drahomanova. Seriia 16: Tvorcha osobystist uchytelia: problemy teorii i praktyky, 17, pp.4-7.

Bakhtin, M.M., 1979. Estetika slovesnogo tvorchestva [Aesthetics of verbal creativity]. Moscow: Iskusstvo.

Bakhtin, M.M., 1986. Problema rechevykh zhanrov [Speech genres issues]. In: Literaturnokriticheskie stati [Literary critical articles].

Bakhtin, M.M., 2000. Avtor i geroi: K filosofskim osnovam gumanitarnykh nauk [Author and hero: Towards the philosophical foundations of the humanities]. St. Petersburg: Azbuka.

Bielikova, V., 2011. Interpretatsiia yak spetsyfichna osnova muzychno-vykonavskoi tvorchosti [Interpretation as a specific basis of music and performance]. Aktualni pytannia mystetskoi pedahohiky, [online] 1, pp.135-138. Available at: <http://apmp.kgpa.km.ua/Files/APMP01/34. pdf $>$ [Accessed 12 August 2021].

Busel, V.T. ed., 2005. Velykyi tlumachnyi slovnyk suchasnoi ukrainskoi movy [Large explanatory dictionary of the modern Ukrainian language]. Kyiv: Perun.

Feinberg, S. The Composer and the Performer. [online] Available at: <http://math.stanford. edu/ ryzhik/Feinberg1.html> [Accessed 12 August 2021].

Fekete, O.V., 2009. Formuvannia vykonavskoi kontseptsii muzychnoho tvoru [Formation of the performing concept of a musical work]. Abstract of the dissertation of the candidate of art history. I.P. Kotlyarevsky Kharkov National University of Arts

Iampolskii, I.M., 1974. Interpretatciia [Interpretation]. In: Keldysh, lu.V. ed., 1974. Muzykalnaia entciklopediia [Musical encyclopedia]. Moscow: Sovetskaia entciklopediia. Ch. 2.

lerhiiev, I., 2015. Rezhyserski intentsii vykonavskoi interpretatsii suchasnoi instrumentalnoi muzyky [Director's intentions of performing interpretation of modern instrumental music]. Mizhnarodnyi visnyk: kulturolohiia, filolohiia, muzykoznavstvo, 2(5), pp.145-150.

Interpretatsiia [Interpretation]. Slovnyk inshomovnykh sliv. [online] Available at: <https://www. jnsm.com.ua/cgi-bin/u/book/sis.pl?Qry=\%B2\%ED\%F2\%E5\%F0\%EF\%F0\%E5\%F2\%E0\%F6\%B3\% FF> [Accessed 12 August 2021].

lutsevych, Yu., 2003. Muzyka: slovnyk-dovidnyk [Music: dictionary-reference book]. Ternopil: Navchalna knyha-Bohdan.

Kliuev, O., 2001. Ontologiia muzyki [Ontology of music]. St. Petersburg: Izdatelstvo SanktPeterburgskogo gosudarstvennogo universiteta.

Maltcev, S., 1991. O psikhologii muzykalnoi improvizatcii [On the psychology of musical improvisation]. Moscow: Muzyka.

Moskalenko, V.G., 2012. Lektcii po muzykalnoi interpretatcii [Lectures on musical interpretation]. Kyiv: Kliaksa.

Padalka, H.M., 2008. Pedahohika mystetstva: (teoriia i metodyka vykladannia mystetskykh dystsyplin) [Art pedagogy: (theory and methods of teaching art disciplines)]. Kyiv: Osvita Ukrainy. 
Pavlova, N.D. and Grebenshchikova, T.A., 2017. Intent-analiz postsobytiinogo diskursa $\mathrm{v}$ internete [Intent-analysis of post-event discourse on the Internet]. Psikhologicheskie issledovaniia, 10 (52), p.8.

Rudnytska, O.P., 1998. Muzyka i kultura osobystosti: problemy suchasnoi pedahohichnoi osvity [Music and personality culture: problems of modern pedagogical education]. Kyiv: IZMN.

Saik, H.F., 2000. Emotsiino-estetychni perezhyvannia muzyky cherez formuvannia vykonavskoi maisternosti studentiv [Emotional and aesthetic experiences of music through the formation of students' performance skills]. Nauka i suchasnist, 22 (2), pp.115-125.

\title{
ИСПОЛНИТЕЛЬСКАЯ ИНТЕРПРЕТАЦИЯ И ИНТЕНЦИЯ КАК ВИДЫ ХУДОЖЕСТВЕННОЙ ДЕЯТЕЛЬНОСТИ В ВОКАЛЬНОМ ИСКУССТВЕ
}

\section{Наталья Могилевская}

e-mail: mogylevska-nataliia@ukr.net; ORCID: 0000-0002-7102-2114

Киевский национальный университет культуры и искусств

\begin{abstract}
Аннотация
Цель исследования - обосновать наличие и важность исполнительской интерпретации и интенции в качестве основных видов художественного творчества в вокальном искусстве. Методы исследования. В решении задач статьи использовались общенаучные, в частности анализ, синтез, интерпретация и обобщение результатов, и специальные методы исследования. Междисциплинарное использование методологического инструментария искусствоведения, психолингвистики, философии искусства и др. позволило обосновать наличие и значение исполнительской интерпретации и интенции в искусстве вокалиста. В частности, для концептуализации представления об интерпретации и интенции вокалиста применялись психосемантические методы, которые исследуют сознание, мотивацию, эмоции личности. Научная новизна заключается в обосновании наличия и важности исполнительской интерпретации и интенции в искусстве вокалиста. Выводы. Обычно музыкально-песенное произведение дает возможность исполнителю-вокалисту прежде всего выразить свои взгляды, переживания, чувства, намерения и под. Поэтому выражение своего внутреннего мира, своего мироощущения, утверждение своего «я» опосредствованно (через интерпретацию музыкального произведения) - основная задача, которую должен решить исполнитель. Часто именно так музыкально-песенный текст, который интерпретирует вокалист, прежде всего становится средством выражения его глубинных ментально-когнитивных намерений, то есть интенций. Поэтому в учреждениях подготовки будущих вокалистов должны обращать внимание на обеспечение условий для ментально-ценностного развития студентов и формирования у них соответствующего духовного мировоззрения.
\end{abstract} Ключевые слова: интерпретация; интенция; исполнитель; вокальное искусство; музыкально-песенный текст; личность 


\title{
PERFORMING INTERPRETATION AND INTENTION AS ARTISTIC ACTIVITIES IN THE ART OF SINGING
}

\section{Nataliia Mohylevska}

e-mail: mogylevska-nataliia@ukr.net; ORCID: 0000-0002-7102-2114

Kyiv National University of Culture and Arts, Kyiv, Ukraine

\begin{abstract}
The purpose of the study is to substantiate the presence and importance of performing interpretations and intentions as the main types of artistic work in the art of singing. Research methodology. Solving the article's issues, there are general scientific, including, analysis, synthesis, interpretation and findings generalization, and special research methods. The interdisciplinary use of the methodologies of Art Studies, Psycholinguistics, Philosophy of Art, etc., made it possible to substantiate the presence and significance of performing interpretations and intentions in the vocalist's mastery. In particular, psychosemantic methods were used to conceptualize the idea of interpretation and intention by the vocalist, which investigate personality's consciousness, motivation, emotions, etc. The scientific novelty lies in substantiating the presence and importance of performing interpretation and intentions in the vocalist's mastery. Conclusions. Usually, a piece of music and song, first of all, allows the vocalist to express their views, experiences, feelings, intentions, etc. Therefore, the main task that the performer must solve is the expression of one's inner world, attitude, and the assertion of the "I" indirectly (through the interpretation of a piece of music). It is often in this way that the lyrics, which the vocalist interprets, first of all, become a means of expressing their deepest mental-cognitive intentions, that is, intentions. Therefore, facilities for training future vocalists should pay attention to providing conditions for students' mental and value development and forming an appropriate spiritual worldview in them.
\end{abstract}

Keywords: interpretation; intention; performer; art of singing; lyric; personality. 